\title{
The Influence of External Institutional Pressures on Local E-Government Adoption and Implementation: A Coercive Perspective within an Indonesian Local E-Government Context
}

\author{
Nurdin Nurdin*, Rosemary Stockdale, and Helana Scheepers \\ Faculty of Information and Communication Technologies \\ Swinburne University of Technology \\ \{Nnurdin, rstockdale, hscheepers\} @swin.edu.au
}

\begin{abstract}
Adoption and implementation of e-government within local government organizations are influenced by many external factors. These factors are often perceived as forces or pressures that influence local government decisions to adopt and implement the initiatives. This study uses the concept of coercive force from institutional theory to explain those external pressures influencing egovernment adoption and implementation within a local government in Bali province in Indonesia. An interpretive case study approach is adopted to empirically understand the external pressures on local government adoption and implementation of e-government. Our findings show that four institutional external forces, central government, regulations, local citizens and limitation in financial resources, have strongly influenced the regency to adopt and implement egovernment systems to improve their administration and services performance.
\end{abstract}

Keywords: institutional theory, coercive, local government, e-government, Indonesia.

\section{Introduction}

Previous studies on e-government adoption and implementation have mostly concentrated on economic or technical factors rather than institutional factors. In fact the majority of challenges surrounding e-government adoption and implementation are related to institutional factors $[1,2]$ including external factors that are often associated with pressures or forces which may lead to success or failure of e-government adoption and implementation.

Studies in Information systems (IS) literature [e.g: 3] argue that the real constraints on IS implementation are mostly related to institutional factors rather than technical factors. However, there is a lack understanding of IS adoption and implementation within the public sectors from an institutional perspective particularly in understanding public organizations as the focus of institutional pressure [4]. While

\footnotetext{
* On leave from STAIN Datokarama Palu and STMIK Bina Mulia Palu Indonesia.
} 
there are some e-government studies [e.g: 5, 6] that address institutional theories to understand such phenomenon, but these studies mainly focus on central government levels and broadly focus on many aspects of institutional factors rather than on a specific aspect of institutional pressure.

This paper specifically focuses on the external institutional pressures that influence e-government systems adoption and implementation at local government level. This type of pressure is considered coercive pressure [e.g: 7, 8, 9] on organizations. Previous studies in IS [e.g: 7,8] have acknowledged that coercive pressures influence the adoption and implementation of IS within organizations. Coercive pressure is "the formal pressure and external pressure exerted upon them by other organizations upon which they are dependent, and the cultural expectations in the society within which the organizations function"[10]. Other studies have also found that organizations' external pressures are exerted by organizations or parent organizations, constituents [8] and regulations [9].

This study, therefore, provides in-depth practical and theoretical insights into the nature of external institutional pressures on e-government adoption and implementation within a local government in an Indonesian setting. In understanding the phenomenon this study applies institutional theory, which previous studies [e.g: 11] have argued, can strongly provide explanation at organizational level. This paper attempts to answer the following research questions: What external institutional factors exert pressure and how do these external factors influence the local government adoption and implementation of e-government?

This paper is structured as follows. Section 2 presents a theoretical review which includes institutional theory, a coercive perspective, and external pressures on egovernment adoption and implementation, and then concludes with a theoretical construct for this study. Section 3 discusses the research methodology, while section 4 presents the case description, followed by findings in section 5. Section 6 and 7 present the discussion and conclusion respectively. Future research and limitation are addressed in the final section.

\section{$2 \quad$ Literature Review}

Institutional theory has been widely applied in understanding adoption and implementation of information technology whether in private sectors [e.g:7, 8] or in public sectors [e.g: 5, 6]. The benefits of applying institutional theory in understanding IT implementation within organizations are twofold; it enables researchers to understand the impacts of various organizational factors that are difficult to quantify such as government regulations and organizational contexts [12] and to conceptualize the dynamic interplay between actors and structure in organizational settings [13] during technology adoption and implementation. In the next sections, we construct our framework to understand those phenomenon.

\subsection{Coercive Forces}

Institutional theory postulates that organizations are influenced by external or internal pressures in forming their structure[14]. These external or internal pressures are 
acknowledged by DiMaggio and Powell[15] as coercive pressures or forces that impose upon organizations to adopt certain policies or to change their structure. Coercive forces have been found to significantly influence an innovation's adoption and implementation in private [e.g: 7, 8] and public organizations [e.g: 16, 17]. However, our study only focuses on external coercive forces on organizations. These coercive forces might be triggered by three factors; such as a parent corporations that an organization relies on, pressure from their constituents $[8,18]$, regulations [14] that are associated with sanctions [14] (such as sanctions that are the result of parent organizations or legislations pressures), and society expectation $[15,18]$.

\subsection{External Pressure on E-Government Adoption and Implementation}

External pressures are forces that come from external government organizations which may influence their policy to adopt and implement e-government. The IS literature [e.g: 7, 8] view these external forces as coercive forces which come from many factors such as parent organizations and constituents. Studies in e-government associate these external forces with factors such as legislation [5, 19], citizens and businesses [2, 5], and central government [20, 21]. However, we acknowledge that the distinction between central government and regulation pressures may be blurring because regulations are also enacted by central government. However, in this study we separate both pressures in an attempt to show that they play a different role in egovernment adoption and implementation.

\section{a. Central Government Pressure}

A central government may launch a policy to deliver better services, such as online services, to their citizens across the country. This policy might be mandatorily adopted and implemented within local authorities because central governments have the power and resources to do so. Central government power may be exerted due to a dependency of lower government agencies to central government in term of resources. For example central government has the power to control financial resources at local levels due to hierarchical systems such as centralization [22] or in another case central government may view local government as an instrument to achieve their policies rather than an autonomous institution representing its local citizens [23]. In this context, local government authorities may be constrained in making decisions to adopt and implement their own policies and programs. As a result, local governments might also be strongly influenced by central government in delivering their services or policies [24] because central government might dictate or mandate the adoption and implementation of the policies according their interests.

\section{b. Regulation Pressure}

Regulation is an institutional element that constraints behaviour and regulates interaction [13]. Scott[25] refers to regulation as explicit and formal rules. In the context of government organizations, rules or regulation are explicitly and formally enacted to structure government institutions to behave in certain ways. Geels [13] stresses that rules or regulations are all about rewards and punishment backed up by sanctions. 
Similarly, government institutions are impelled by the rules to implement certain initiatives or policies such as e-government systems. Failure to abide to the regulation might lead to sanctions. This includes sanctions when the e-government systems do not meet criteria or targets [26] determined by regulations.

A regulation on freedom of information and transparency is one vivid example that imposes the requirement for government organizations, including local governments, to adopt and implement e-government systems. These regulation have been enforced in many countries such as in USA [27] and Spain [28]. Agusti (2011) argues that the diffusion of information through electronic means within the public sector in Spain was caused by the formulation of new regulations. The regulations cover the general principle of electronic means in providing information to citizens and citizens' right to access the information. All public organizations should abide by this regulation. Regulations may constrain government organizations in that they influence the adoption and implement of e-government within their organizations[29].This may imply that regulations can be a source of institutional pressure that has the ability to force government organizations to adopt certain policies.

\section{c. Local Citizens and Business Pressure}

As argued by Markus \& Robey [30], organizations try to find solutions as demanded by their external clients. In the context of e-government, citizens' and local businesses' demand for online services have become a pressure for local government to adopt and implement e-government [2]. For example, when local firms implement online commerce to ease their businesses to citizens relationship, the local citizens experience new convenient ways of doing businesses. These new experiences result in an expectation of similar services from their local government. Then the local government comes under pressure to adopt and implement new technology such as egovernment systems.

Citizens demand transparency from government bodies that allows citizens to obtain online information and make transactions at any time; another example of external institutional pressure. In response to this demand, local governments implement technology that promotes openness[31, 32]. Government organizations' efforts to be transparent might also lead to changes their daily practices. For example, they have to reveal their work procedures to citizens and other stakeholders in order to be transparent [32]. This pressure may be viewed as a driver for e-government adoption and implementation within local government organizations.

\subsection{Theoretical Constructs}

The theoretical concepts discussed above are summarized to establish our theoretical construct as depicted in Figure 1 below. In this study, coercive forces are considered as external forces that influence local government decision to adopt and implement egovernment systems within organizations. We argue that the coercive forces are derived from three external factors; central government, regulations, and local citizens and businesses. The three external factors exert their influences throughout the process e-government systems adoption and implementation. 


\section{External factors}

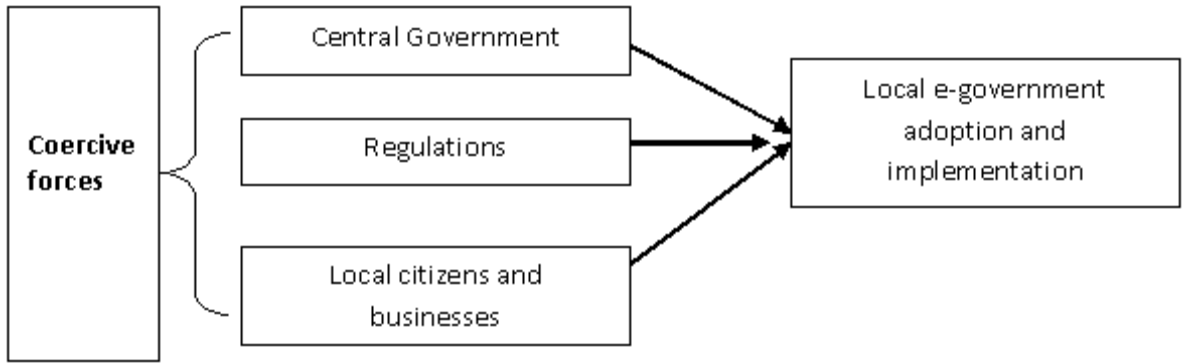

Fig. 1. Theoretical Constructs

\section{$3 \quad$ Research Methodology}

This research uses a single case study of local e-government adoption and implementation in Jembrana regency in the Bali province in Indonesia. The case study is better applied to understand phenomenon when the boundary between the phenomenon and context are not clearly defined and requires an in-depth study of a case or cases [33]. For example, e-government adoption and implementation involves the complexity of government institutions' relationships [1] which requires close examination. This complexity emerges as the result of institutions' interaction, such as social, political, and cultural, during the adoption and implementation, and this complexity can be understood through interpretive case study research [34-36]. This approach provides the researcher with the opportunity to reflect on the complexity of local government organizations and employees' sense making during the emergent situation in egovernment implementation. As a result, this approach could assist the current poor understanding and limited theoretical development in addressing the above research question.

Table 1. Participants characteristics and roles

\begin{tabular}{|l|c|c|}
\hline Participants' Role & $\begin{array}{c}\text { Number of } \\
\text { participants }\end{array}$ & $\begin{array}{c}\text { Participants } \\
\text { code }\end{array}$ \\
\hline Management level & 4 & A, B, C, and D \\
\hline IT/ IS Team Members & 5 & $\begin{array}{c}\text { E, F, G, H, and } \\
\text { I }\end{array}$ \\
\hline Operational IT/IS staff & 3 & J, K, and L \\
\hline
\end{tabular}

The primary data were gathered through semi-structured interviews which involved 12 participants from management level to technical employees (table 1). Data collection from different levels will contribute to drawing more informed conclusion of this study [37]. During field visits, field notes were made and written materials that support the main data were also collected. The interviews were carried out in Indonesian. The interviews were transcribed and translated into English. This allows the 
other two researchers, who do not understand Indonesian, to assist in the coding process as well as to establish research transparency. The interviews along with field data, such as field notes and other written material which have been collected, were coded in Indonesian language to maintain the original meaning and sense. All codes were translated into English when they were transferred into this paper. Meanwhile, coding broadly followed Strauss and Corbin [38] in which the data analysis was carried out with three iterations; open coding, axial coding and selective coding.

\section{Case Description}

Indonesia has a unique local government power structure where the greatest autonomy is transferred to the second level of local government (regencies and cities) and not to provincial levels [39]. According to Regional Autonomy Law No. 32/2004, central government has granted full autonomy to the regencies and cities to manage their development (except law, monetary, defence, and foreign affairs). Based on this regulation, governments at provincial level do not have the power to impose or mandate regencies or cities to adopt certain policies and regulations. Provincial level governments function as coordinators and supervisors of the lower levels (regencies and cities). Regencies and cities have a direct relationship to central government and can adopt new policies from central government directly without involving the provincial level.

Jembrana regency is one of five regencies in Bali province Indonesia. Despite Bali's popularity in the tourism industry and the generation of more income for the province, Jembrana regency is not a main destination for tourists. The tourism development in this regency is slower than other regencies. Consequently, unlike other regencies in Bali the main source of this regency's income is not from tourism but from farming. However, farming does not produce sufficient income to support the regency development since farming relies on traditional methods. This regency also does not have mining and big industries that support local government income. Most of the industries are home industries and small medium industries such as handicraft and religious related arts. Their income is low and unable to support its development if they only relied on local revenue. Therefore, the local government budget is mostly supported by central government annual transfer.

\section{$5 \quad$ Findings}

This section describes the findings from the interview, field notes, and other written documents. Based on the analysis, it was found that a number of external institutional factors have influenced the adoption and implementation of local e-government in Jembrana regency.

\section{a. Central Government Pressure}

Our findings show that Indonesian central government, through a number of central government departments, has contributed to e-government adoption and implementation within Jembrana regency. Participants indicated that early initiative of information 
technology (IT) adoption and implementation within their regency was influenced directly and indirectly by central government pressure. The initial IT adoption and implementation within the regency central office, for example, was started when the BPPT introduced the use of computers in the regency to improve the local government work performance. One of the participant states:

Regarding e-government we started working with BPPT. It happened in 2001, right after the regent serve done year of his leadership.... After that, we were introduced to computers to support local government performance (Participant I)

The early IT introduction within central regency office has led to the introduction of computers to district levels in the following year (2002). Each district office was provided a computer to perform their work and provide service to their citizens.

An early e-government application, which supports online job accomplishment and data sharing was initiated by the BPPT by implementing a virtual office system which is called KANTAYA in 2004. The importance of this initiation is highlighted by participant $\mathrm{C}$.

Then an application which is called KANTAYA (virtual office) was implemented in 2004. This was an embryo for the development of e-government in the regency of Jembrana.

The presence of the KANTAYA system enabled the implementation of other central government based systems such as SIADINDA (regional department accountancy information system). SIADENDA is a compulsory system to manage finance within all departments in the regency. One participant addresses this issue as follows:

The system is mandated by the financial department in Jakarta and in this office. All departments must use SIADINDA because all financial data must be put into the system with similar format, otherwise our financial reports will be rejected by central government (Participant J)

SIAK (demographic information systems) is also a system transferred from Ministry of State Affair in Jakarta. The system was mandatory adopted and implemented by central government to improve local population administration since 2007. Despite demanding the regency to adopt and implement the system, the ministry of internal affairs did not fully transfer the system. The impact of this systems transfer policy has resulted in a lack of skills by the staff to deal with the system as addressed by the following participant:

The SIAK system was transferred from Ministry of state affairs office in Jakarta........ Actually, the system is a bundled system which is ready to use. We do not know what is behind the system, we just operate it. If we encounter system malfunction, we have to contact them (Participant $\mathrm{K}$ )

The mandatory use of SIAK system within all regency levels is due to the central government policy to implement e-ID (electronic identification) in 2011. All databases for e-ID implementation come from the SIAK system. e-ID has become a mandatory system from central government to be adopted and implemented at regencies level in Indonesia from early 2011 and must be adopted and implemented completely in all regencies by 2013 . 


\section{b. Regulation Pressure}

E-government adoption and implementation in Indonesia context is regulated with presidential instruction no. 3 year 2003. The presidential instruction states that all government institutions from central to local levels must adopt and implement egovernment. During the interviews, participants explicitly referred to the regulation regarding e-government adoption and implementation within the regency. The presidential instruction must be used as a legal basis for e-government adoption and implementation and also for annual budget proposal negotiation with local parliament and central government. For example, one participant indicates:

Allocation of annual budget for IT implementation is not easy because we have so many development priorities in this regency. We have to convince local parliament members and central government. However, since e-government implementation has been regulated by the presidential instruction, we just refer to the regulation so they can not reject it (Participant A)

In addition, the presidential instruction has contributed to the enactment of other government regulations at ministry levels that mandate all local governments to adopt and implement certain e-government systems. The findings show that even though some of e-government systems were implemented based on the regency initiative, most important e-government systems that improve the local government bureaucracy, administration and citizens services were strongly mandated by the regulations. SIMAKDA (Local government budgeting and financial information system management), for example, have been implemented based on Central government regulation No. 58 year 2005 and Ministry of Internal State Affairs No. 55 year 2008. Meanwhile, e-ID (electronic identification) was mandated with presidential decree number 26 year 2009.

Central government regulation number 14 year 2008 imposes all government institutions to provide information to citizens. This regulation is a well-known regulation regarding government information disclosure which is published through the local government web sites. A participant refers to that regulation as follows:

There's a regulation of public disclosure; so, government should be transparent and IT will help government to be transparent ......the information associated with the budget or local government regulations must be published (Participant B)

Regulation at local level has also been enacted to impose all departments to adopt and implement e-government within their organization to improve regency services performance. The influence of regulation has caused the local government to adopt and implement the e-government systems. In the context regulations pressure, resistance might not possible because resistance to the policy may result in a punishment such as their financial reports may be rejected.

\section{c. Local Citizens and Businesses Pressure}

Citizens and local business influences have played a significant role in e-government adoption and implementation in Jembrana regency. Their influences relate to better government services provision performance. One participant indicates this issue as follows: 
Today citizens become more and more smart, and they expect a responsive and efficient government that is able to provide better services for them. In response to their expectation we have an ambition that we must use technology in our daily work; it is e-government (Participant B)

In response to the citizens' and to business demands, the regency implemented a SMS centre system that is able to accommodate and absorb their enquiries. The SMS centre has been considered an important e-government system that helps local government respond quickly to citizens' complaints related to local development as well as accommodate their participation in local development planning. One participant says:

This application (SMS centre) is really important to be implemented and used by responsible employees every day because it consists of complaints and suggestions from citizens that need to be followed up quickly (Participant B)

All the messages from citizens come to the system and then each relevant department (SKPD) must respond to the citizens' inquiries.

Similarly, another participant from licensing department indicates citizens and businesses pressure to implement a system which able to improve efficiency in licensing process.

The system was implemented as increase demand in licensing process from citizens and business. Previously, it took a long time to process a license and the processes were not in order. Sometimes people who apply earlier did not get their licenses first and it caused tension between us and the applicants because they think we had done something negative (Participant L)

Adoption and the implementation of e-library system that allows citizens to find library collections quicker and easier was also as a result of citizens pressure. Participant from the library says:

The visitors want to find books quickly, while the existing system does not allow visitors to use the system because it is only for staff log in (Participant $\mathrm{J}$ )

Previous system was integrated with the KANTAYA system which allows only government employees to use the system and search a library collection based on a citizens (visitors) demand. However, when more and more citizens visit library and want to find library collections in a fast way, the government library staff were unable to response to the increasing demand. Library IT staff, then, developed the e-library system that allows visitors to do self-retrieve.

\section{d. Regency Limitation Pressure}

Jembrana regency is a relatively poor regency compared to other regencies within Bali province. Their revenue relies on farming, small and medium enterprise, central government annual budget transfer. In 2010, the regency annual budget comprised of $84.5 \%$ central government transfer, $10.4 \%$ from provincial tax sharing and grant, and only $5.1 \%$ of the budget come from the local government revenue. The regency limitation in budget is realized by all citizens in the regency as stated by the following participant: 
The main problem is lack of funds. We got small budget allocation because our regional budget is relatively small compared to other regions. Everyone knows about it (Participant D)

This situation has encouraged local leaders and employees to think innovatively by implementing e-government as a tool to cope with local budged hardship. One participant said:

Since we don't have money, so we think of innovation. If we are continuously poor, we'll be rejected by people. Then we think what we can do with IT to improve our region (Participant B)

As the regency does not have reliable industries, tourism, and natural resources that can support their annual budget, the regency uses IT as a solution to minimize their operational cost in serving citizens and promote their regency through their website. A participant from management level expresses his comment as follows:

You know we have limited budget because we do not have many industries, tourism or natural resources like other regencies in Bali. We only rely on farming and some small natural resources. I think implementation IT within our office is one way to save our operational cost and time (Participant $\mathrm{C}$ )

Another participant expressed similar concern as follows:

Our basic principle is that "we are not rich but we are creative and innovative". You know this regency is not as rich as other regencies. By implementing IT we also expect that citizens get benefits from it (Participant $\mathrm{A}$ )

The importance of e-government implementation to reduce the regency budget expenditure and to cope with the regency budget limitation has caused Jembrana regency leaders and IT team to think creatively. The IT team designed a variety of egovernment systems to support the development of the regency and to improve service delivery to citizens. For example, they created cheaper communication application systems that allow citizens and local government to communicate free of charge, such as J-Net (Jimbarwana network), VOIP (voice over internet protocol), and SMS centre.

\section{Discussion}

Delmas \&Toffel [40] argue that the sources of pressure that impose on an institution to adopt certain policies mostly come from external institutions such as government, regulation, and constituents as found above. Our findings, however, in the context of e-government adoption and implementation within local government institutions in Indonesia, found that regency limitations of economic or poverty also force a local government institution to adopt and implement technology. The regency limitation in generating revenue from their local resources and citizens has forced the regency leaders and staff to be innovative. In this study context, poverty is viewed as a source of innovation. Poverty as a source of inspiration to innovate is not well addressed in information technology and e-government adoption and implementation but a study conducted by Reij\& Waters-Bayer [41] on farmers' poverty in Africa found that the 
adoption of new innovation by farmers were encouraged by their poverty. This means that poverty or peoples' economic limitation has inspired them to adopt an innovation to improve their well-being.

Similarly, Jembrana regency has adopted and implemented e-government as the result of the regency limitation in economic resources. The regency was forced to innovate in improving government institutions performance to provide better services for their citizens. This resulted in improving the local government performance through cost reductions and promotes local tourism and businesses to external agencies. As a result the regency and citizens can improve their well-being and is able to generate more revenue.

There is a limited amount of literature that addresses poverty in e-government adoption and implementation [e.g: 42, 43, 44]. Study findings do not explain how poverty triggers the local authorities to adopt e-government but rather, they focus on benefits provided by e-government for local citizens and the use of e-government to alleviate poverty. Our findings may inspire other government institutions to adopt and implement similar initiatives, particularly government institutions with a similar context with Jembrana regency in Bali province Indonesia.

There might be a question from readers regarding how a poor budget regency adopts and implements technology within their organizations because it consumes a lot of their budget which should be used for their regional development. However, institutional theories argue that "an institution will be innovated if the expected net gains exceed the expected costs"[45]. Jembrana regency has been able to generate direct and indirect benefits from the e-government more than the costs they invested because the regency institutions are able to reduce operational costs and improve service deliveries, while citizens able to access government service effectively.

\section{Conclusion}

The findings show that three external pressures proposed in our theoretical framework have influenced e-government adoption and implementation within Jembrana regency. Interviews, document and field notes analysis also reveals that the regency limitation in financial resources also contribute to the adoption and implementation of e-government. The limitation forces the regency leaders to innovate by adopting and implementing e-government to cope with the limitation. As a result our prior theoretical construct to conduct this study is resumed and revised as shown in the following figure 2. External institutional pressures that influence local e-government adoption and implementation are not limited to the three previously found in IS and e-government adoption and implementation, but in this case study the adoption and implementation of e-government is also influenced by the regency limitation in economic resources.

\section{$8 \quad$ Limitation and Future Research}

This study was carried out within a local government in Indonesia and the findings may provide a new perspective on external institutional pressure on e-government 
External Factors

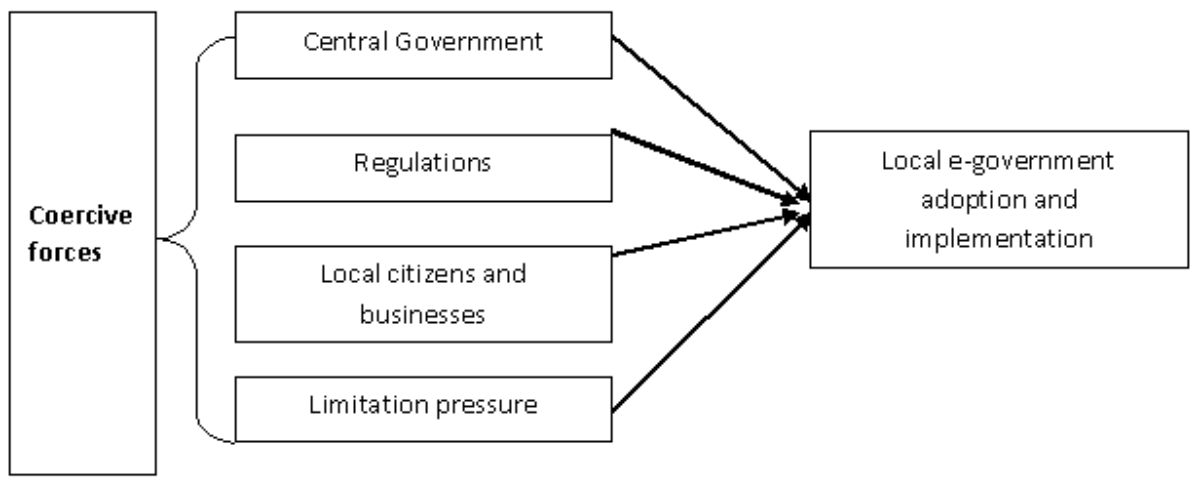

Fig. 2. Concluded external pressure on Local e-government

adoption and implementation within local government levels. Since this study was carried out at one local government and only focuses on external institutional pressures, the findings may lack generalizability. However, our in-depth study of the case phenomenon and the results can potentially contribute valuable theoretical and practical knowledge to the community [46]

Therefore, future research needs to explore internal institutional to provide a broader perspective of institutional pressures on e-government adoption and implementation within local government organizations. Future research also need to be carried out within multi-site studies to increase generalizability as suggested by Schofiell [47]. This strategy might produce a more rigorous result as a basis for generalization to other e-government adoption and implementation cases.

\section{References}

1. Heeks, R., Bailur, S.: Analyzing E-Government Research: Perspectives, Philosophies, Theories, Method, and Practice. Government Information Quarterly 24(2), 243-263 (2007)

2. Ho, A.T.-K., Ni, A.Y.: Explaining the Adoption of E-Government Features: A Case Study of IOWA County Treasurer's Offices. The American Review of Public Administration 34(2), 164-180 (2004)

3. Baddeley, M.: Using E-cash in the New Economy: An Economic Analysis of MicroPayment Systems. Journal of Electronic Commerce Research 5(4), 239-253 (2004)

4. Frumkin, P., Gelaskiewicz, J.: Institutional Isomorphism and Public Sector Organizations. Journal of Public Administration Research \& Theory, 283-307 (2004)

5. Jun, K.-N., Weare, C.: Institutional Motivations in the Adoption of Innovations: The Case of E-Government. Journal of Public Administration Research \& Theory 21(3), 495-519 (2010)

6. Kim, S., Kim, H.J., Lee, H.: An institutional analysis of an e-government system for anticorruption: The case of OPEN. Government Information Quarterly 26(1), 42-50 (2009)

7. Liang, H., et al.: Assimilation of Enterprise Systems: The Effect of Institutional Pressure and The Mediating Role of Top Management. MIS Quarterly 31(1), 58-87 (2007)

8. Teo, H.H., Wei, K.K., Benbasat, I.: Predicting Intention to Adopt: Interorganizational Linkages: An Institutional Perspective. MIS Quarterly 27(1), 19-49 (2003) 
9. Tolbert, P.S., Zucker, L.G.: Institutional Sources of of Change in the Formal Structure of Organizations: The Diffusion of Civil Services Reform, 1880-1935. Administrative Science Quarterly 28(1), 22-39 (1983)

10. DiMaggio, P.J., Powell, W.W.: The Iron Cage Revisited: Institutional Isomorphism And Collective Rationality In Organizational Fields. American Sociological Review 48(2), 147-160 (1983)

11. Jensen, T.B., Kjaergaard, A., Svejvig, P.: Using Institutional Theory with Sensemaking Theory: A Case Study of Information System Implementation in Healthcare. Journal of Information Technology 24, 343-353 (2009)

12. Tsamenyi, M., Cullen, J., González, J.M.G.: Changes in accounting and financial information system in a Spanish electricity company: A new institutional theory analysis. Management Accounting Research 17(4), 409-432 (2006)

13. Geels, F.W.: From Sectoral System of Innovation to Socio-Technical Systems Insight about Dynamics and Change from Sociology and Institutional Theory. Research Policy 33(6-7), 897-920 (2004)

14. Zucker, L.G.: Institutional Theories of Organization Annual Review Sociology 13, 443464 (1987)

15. DiMaggio, P.J., Powell, W.W.: The Iron Cage Revisited: Institutional Isomorphism and Collective rationality in Organizational Fields. In: Powell, W.W., DiMaggio, P.J. (eds.) The New Institutionalism in Organizational Analysis. The University of Chicago Press, Chicago (1991)

16. Berke, P.R., Dixon, J., Ericksen, N.: Coercive and cooperative intergovernmental mandates: a comparative analysis of Florida and New Zealand environmental plans. Environment and Planning B: Planning and Design 24(3), 451-468 (1997)

17. Cho, C.-L., Wright, D.S.: Managing Carrots and Sticks: Changes in State Administrators' Perceptions of Cooperative and Coercive Federalism During the 1990s. Publius: The Journal of Federalism 31(2), 57-80 (2001)

18. Mizruchi, M.S., Fein, L.C.: The Social Construction of Organizational Knowledge: A Study of the Uses of Coercive, Mimetic, and Normative Isomorphism. Administrative Science Quarterly 44(4), 653-683 (1999)

19. Kamal, M., Weerakkody, V., Irani, Z.: Analyzing the role of stakeholders in the adoption of technology integration solutions in UK local government: An exploratory study. Government Information Quarterly 28(2), 200-210 (2011)

20. Beynon-Davies, P., Martin, S.: Electronic Local government and the Modernization Agenda: Progress and Prospects for Public Service Improvement. Local Government Studies 30(2), 214-229 (2004)

21. Irani, Z., et al.: Evaluating E-Government: Learning From the Experiences of Two Local UK Authorities. Information Systems Journal 15(1), 61-82 (2005)

22. Elander, I., Montin, S.: Decentralisation and Control: central-local government relations in Sweden. Policy \& Politics 18(3), 165-180 (1990)

23. Wollmann, H.: Local Government Systems: From Historic Divergence Towards Convergence? Great Britain, France, and Germany as Comparative Case in Point, in Environment and Planning C: Government and Policy, pp. 33-55 (2000)

24. Wilson, D.: Unravelling control freakery: redefining central-local government relations. British Journal of Politics \& International Relations 5(3), 317-346 (2003)

25. Scott, R.W.: Institutions and Organizations. Sage Publications, London (1995)

26. Griffin, D., Halpin, E.: An Exploratory Evaluation of UK Local e-Government From an Accountability Perspective. The Electronic Journal of e-Government 3(1), 13-28 (2005) 
27. Apfelroth, J.: The Open Government Act: A Proposed Bill to Ensure The Efficient Implementation of the Freedom of Information Act. Administrative Law Review 58(1), 219-234 (2006)

28. Agusti, C.-i.-M.: The Regulation of Diffusion of Public sector Information via Electronic Means: Lessons from the Spanish Regulation. Government Information Quarterly 28(2), 188-199 (2011)

29. Devadoss, P.R., Pan, S.L., Huang, J.C.: Structurational analysis of e-government initiatives: a case study of SCO. Decision Support Systems 34(3), 253-269 (2003)

30. Markus, M.L., Robey, D.: Information Technology and Organizational Change: Causal Structural in Theory and research. Management Science 34(5), 583-598 (1988)

31. Deakins, E., Dillon, S.M.: E-Government in New Zealand: the Local Authority Perspective. The International Journal of Public Sector Management 15(5), 375-398 (2002)

32. Bertot, J.C., Jaeger, P.T., Grimes, J.M.: Using ICTs to create a culture of transparency: Egovernment and social media as openness and anti-corruption tools for societies. Government Information Quarterly 27(3), 264-271 (2010)

33. Yin, R.K.: The Case Study Crisis: Some Answers. Administrative Science Quarterly 26(1), 58-65 (1987)

34. Walsham, G.: Interpreting Case Studies in IS Research: Nature and Method. European Journal of Information Systems 4, 74-81 (1995)

35. Walsham, G.: Doing Interpretive Research. European Journal of Information Systems 15(3), 320-330 (2006)

36. Stockdale, R., Standing, C.: An interpretive approach to evaluating information systems: A content, context, process framework. European Journal of Operational Research 173(3), 1090-1102 (2006)

37. Scheepers, R., Scheepers, H.: Contexts of Relevance in Explanatory Case Studies in Information Systems: Ubiquitous Information Technology Implementation in Organizations. In: ICIS 2003 Proceedings, paper 3 (2003)

38. Strauss, A., Corbin, J.M.: Basics of Qualitative Research: Grounded Theory Procedures and Techniques. Sage Publications, Inc., Thousand Oaks (1990)

39. Depdagri (2004) Penjelasan atas Undang Undang Republik Indonesia Nomor. 32 Tahun (2004)

40. Delmas, M., Toffel, M.W.: Stakeholders and Environmental Management Practices: An Institutional Framework. Business and Strategy Management 13, 209-222 (2004)

41. Reij, C., Waters-Bayer, A.: Entering Research and Development in Land Husbandry Through Farmer Innovation. In: Reij, C., Watres-Bayer, A. (eds.) Farmer Innovation in Africa: A Source of Inspiration for Agricultural Development. Earthscan Publications Ltd, London (2001)

42. Martin, B., Byrne, J.: Implementing E-Government: Widening the Lens. Electronic Journal of E-Government 1(1), 11-22 (2003)

43. Moodley, S.: The Promise of E-Development? A Critical Assessment of the State ICT for Poverty Reduction Discourse in South Africa. In: Perspectives on Global Development \& Technology, pp. 1-26. Brill Academic Publishers (2005)

44. Cecchini, S., Raina, M.: Electronic Government and the Rural Poor: The Case of Gyandoot. Information Technologies and International Development 2(2), 65-75 (2004)

45. Davis, L.E., North, D.C.: Institutional Change and American Economic Growth. Cambridge University Press, London (1971)

46. Myers, M.: Qualitative Research and The Generalizability, The Qualitative Report (2000)

47. Schofiell, J.W.: The Qualitative Researcher's Companion. In: Huberman, A.M., Miles, M.B. (eds.) Sage Publications, London (2002) 